\title{
High-rate algal pond treatment for water reuse in an integrated marine fish recirculating system: effect on water quality and sea bass growth
}

\author{
Geneviève Deviller ${ }^{a}$, Catherine Aliaume ${ }^{b}$, Miguel Angel Franco Nava $^{c}$, Claude Casellas $^{a}$ and \\ Jean Paul Blancheton ${ }^{\mathrm{d}_{*}}$
}

\author{
a Département Sciences de l'environnement et Santé Publique, UMR 5556, Faculté de Pharmacie, 15, \\ av. Charles Flahault 34060, Montpellier, France \\ ${ }^{\mathrm{b}}$ Laboratoire des Écosystèmes Lagunaires, CC093, Université Montpellier II, Place E. Bataillon \\ 34095, Montpellier Cedex 05, France \\ ${ }^{c}$ ENSAR, 65 rue de St. Brieuc, CS 84215, 35042, Rennes Cedex, France \\ d IFREMER, Chemin de Maguelone, 34250, Palavas-les-flots, France \\ *: Corresponding author. Tel.: +33-4-67504112; fax: +33-4-67682885.
}

\begin{abstract}
A high-rate algae pond (HRAP) was tested as a second loop of water treatment in a recirculating fish rearing system to reduce water requirements and nutrient discharge levels. Three duplicated groups of sea bass (mean initial body weight $35 \pm 11 \mathrm{~g}$ ) were reared under different system conditions (flow-through system, recirculating system and recirculating system with HRAP) for 1 year. Fish survival rate was higher in the system with HRAP, and their mean body weight was statistically higher $(p<0.05)$ during the month of maximal climatic conditions for algae photosynthesis. After 266 days of experiment, mean fish weight was significantly higher $(p<0.05)$ in the flow-through system than in the recirculating systems. Final fish weight was $15 \%$ higher in the flow-through system than in recirculating systems and was related to a higher daily-ingested food. The comparison of mean annual nutrient concentrations in the recirculating systems gives a statistically significant reduction of $25 \%$ of nitrogen $(p<0.01)$ and $9 \%$ of phosphates $(p<0.01)$ due to the HRAP. Absorption of nitrate form is responsible for nitrogen removal and is related to climatic conditions for algae growth. The phosphate precipitation at high $\mathrm{pH}$ (above 8) was not considered. The maximal removal rates were $0.5 \pm 0.2 \mathrm{~g} \mathrm{~N}$ $\mathrm{m}-2$ day -1 and $0.03 \pm 0.02 \mathrm{~g} \mathrm{P} \mathrm{m}-2$ day -1 for nitrates and phosphates, respectively, and were obtained during the optimal climatic conditions and the shortest algae harvesting frequency. These results are favourable to complete reuse of the HRAP treated water, all year long, in the recirculating rearing systems. In order to improve nitrate and phosphate removal rates, a periodic harvesting of algae is necessary and a higher water inflow in HRAP should partly make up for inorganic carbon depletion in high nitrate and phosphate effluents.
\end{abstract}

Keywords: High-rate algae pond; Recirculation; Fish growth; Nitrogen; Phosphorus; Sustainability 


\section{Introduction}

One of the main drawbacks of fish culture lies in the waste derived from fish feed and its metabolic end products. The main products are uneaten food, faeces and excreted, dissolved, inorganic nutrients which are transported in the water in various concentrations. In flushed rearing systems, such as cage culture in open sea or in raceways, waste output is diluted at low concentrations in a large volume. However, direct discharge of aquaculture waste is internationally disapproved and recirculating systems are developed to limit the impact of aquaculture on aquatic environments. Reused water systems reduce water replacement rates and waste volume but they are limited by the accumulation of toxic ammonia excreted by fish. Recent studies have shown the efficiency of algae biofilters in removing nitrogen from low ammonia fish effluents (Cohen and Neori, 1991; Jimenez Del Rio et al., 1996; Schuenhoff et al., 2003). In semi-closed recirculating systems, the biological filter transforms toxic ammonia to nitrate via nitrifying bacteria. Dissolved nitrate and phosphate levels accumulated in the water of such systems depend on fish density and water replacement flow rate (Pagand et al., 2000a). In an experimental research center (Ifremer, Palavas) a high rate algal pond (HRAP) was tested to treat the effluents from a recirculating sea water circuit. This technique, described by Oswald (1963), includes mechanically induced turbulence to enhance algal productivity. The algae that develop spontaneously in those effluents are macroalgae species (Ulva, Enteromorpha and Cladophora). Pagand et al. (2000b) demonstrated that the HRAP may be used to treat the marine fish effluents of recirculating circuits characterised by high nutrients, and specifically high nitrate concentrations. They obtained a significant reduction of nitrate and phosphate concentration, with strong seasonal variations. Also, the absence of toxic phytoplancton, a high $\mathrm{pH}$ value and oxygen concentration in the treated effluent were in accordance with its re-injection into the fish tanks. 
The objectives of this experiment were to evaluate (1) the long term effect of the reuse of HRAP treated water on fish performance by comparing three rearing systems and (2) the purification capacities of the HRAP on a high concentrated effluent during one year.

\section{Materials and methods}

\subsection{Experimental fish rearing systems}

During this experiment, fish growth was compared in three experimental-scale rearing systems: one flow-through system (FTS); one recirculating aquaculture system (RAS) and one recirculating aquaculture system with HRAP (RAS+HRAP). A general diagram of the systems is shown on Fig.1 and their operational characteristics are indicated in Table 1. The temperature, $\mathrm{pH}$, dissolved oxygen concentration and photoperiod in the tanks were adjusted within the following ranges: $22 \pm 1^{\circ} \mathrm{C}, 6.5-8$, 6-10 $\mathrm{mg} \mathrm{l}^{-1}$ and 16 hours light per day, respectively. Each system was equipped with two self cleaning fish tanks of $2 \mathrm{~m}^{3}$ each, in which water replacement rate was $3 \mathrm{~m}^{3} \mathrm{~h}^{-1}$ per tank. 
Fig.1. A general diagram of the rearing systems (numbers are explained in Table 1): Flow through (1,6,8 \& 9); Recirculating (1,2,3,4,5,6,7,8 \& 9) and Recirculating with $\operatorname{HRAP}(1,2,3,4,5,6,7,8,9$ \& 10)

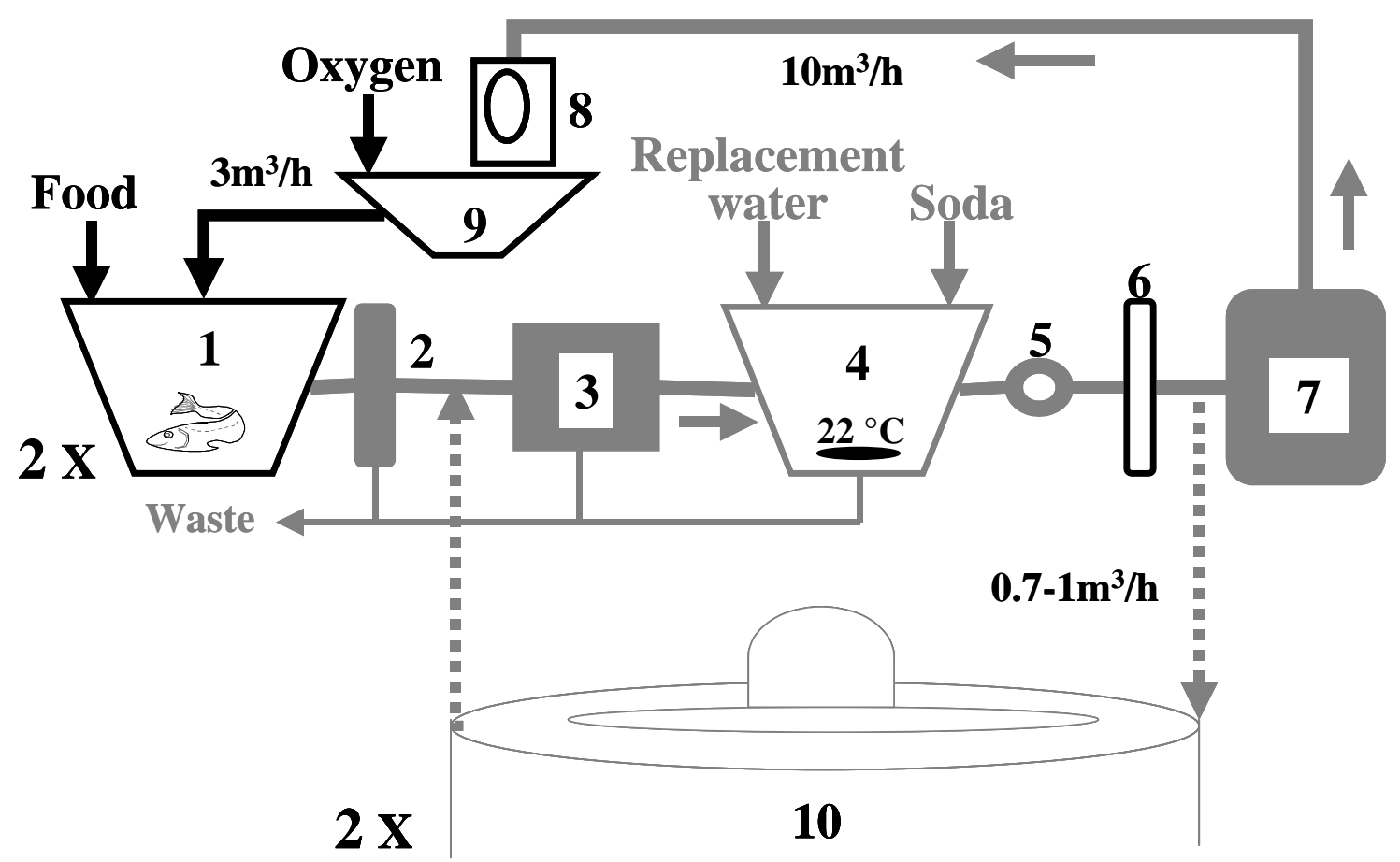


Table 1.Characteristics of the different components of the rearing systems

\begin{tabular}{|c|c|c|c|}
\hline Number & Components & Functions & Characteristics \\
\hline 1 & Fish tank & Fish stocking & $2 \mathrm{~m}^{3}$ \\
\hline 2 & Particle trap & Faeces and uneaten food collection & \\
\hline 3 & Mechanical filter & Removal of small particles & $30 \mu \mathrm{m}$ mesh filter \\
\hline 4 & Pumping tank & $\begin{array}{l}\text { pH regulation } \\
\text { Replacement water } \\
\text { Thermoregulation }\end{array}$ & $\begin{array}{l}0.5 \mathrm{~m}^{3} \\
\text { Soda adding, Sand filtered } \\
\text { Heat exchanger or rheostat }\end{array}$ \\
\hline 5 & Pump & Recirculation of water & $10 \mathrm{~m}^{3} / \mathrm{h}$ \\
\hline 6 & UV lamp & Bacteria control & $20.10^{-3} \mathrm{~J} / \mathrm{cm}^{2}$ \\
\hline 7 & Biological filter & Nitrification & $\begin{array}{l}0.7 \mathrm{~m}^{3} \\
\text { Biogrog }^{\circledR}\end{array}$ \\
\hline 8 & Packed column & $\mathrm{CO}_{2}$ stripping & $\begin{array}{l}\text { Counter current air/water } \\
\text { packed column }\end{array}$ \\
\hline 9 & Storage tank & Suroxygenation & $0.2 \mathrm{~m}^{3}$ \\
\hline 10 & HRAP & Removal of dissolved nutrients & $\begin{array}{l}\text { Bubbling of pure oxygen } \\
6 \mathrm{~m}^{3}: 12 \mathrm{~m}^{2} \times 0.5 \mathrm{~m} \\
\text { Paddle wheel }\end{array}$ \\
\hline
\end{tabular}

In the FTS $\left(5 \mathrm{~m}^{3}\right)$, considered as a control, filtered water $\left(6 \mathrm{~m}^{3} \mathrm{~h}^{-1}\right)$ passed through a UV lamp, a heat exchanger, a degassing column and a oxygenation device before entering the fish tanks. In the RAS (6 $\mathrm{m}^{3}$ ) described by Blancheton (2000), the fish tanks, equipped with particle traps, were connected to a recirculation loop $\left(10 \mathrm{~m}^{3} \mathrm{~h}^{-1}\right)$ constituted of a mechanical filter, a pumping tank, a UV lamp, a biological filter, a degassing column and a oxygenation device. The replacement water was adjusted twice a week according to the ingested food quantity, in order to maintain a constant ratio $\mathrm{R}_{\text {feed/water }}=$ $0.4 \mathrm{~kg} \mathrm{~m}^{-3}$. Rinsing freshwater of the mechanical filters was considered as part of the replacement water.

The RAS+HRAP is similar to the RAS but a part of the effluent $\left(0.7-1 \mathrm{~m}^{3} \mathrm{~h}^{-1}\right)$ was taken before the biological filter to be treated in two outdoor HRAP as described by Pagand et al. (2000b). After filtration to remove the macroalgae ( $1 \mathrm{~mm}$ mesh size), the treated effluent was pumped into the recirculation loop at the entrance of the mechanical filter. After harvesting of the algae every fifteen days during winter and spring and weekly during summer and autumn, the HRAP was restocked 
between 0.1 to $0.6 \mathrm{~g}$ of dry weight per liter $\left(\mathrm{g}-\mathrm{DW} \mathrm{l}^{-1}\right.$ ). In order to compare our results with published data, the water flow rate in the HRAP was expressed as 0.8-1.7 volume of pond per day (vol $\mathrm{d}^{-1}$ ).

\subsection{Fish origin and food characteristics}

The fish were sea bass (Dicentrarchus labrax) from a nearby farm. They were 9 months old and their average weight was $35 \pm 11 \mathrm{~g}$ at the beginning of the experiment. They were randomly distributed in the six rearing tanks of the different systems. The fish density was $10 \pm 2 \mathrm{~kg} \mathrm{~m}^{-3}$. The experiment lasted one year and only dead animals were removed between the beginning and the end, therefore fish density in the tanks consequently increased. They quickly acclimated to the tactile trigger of the self feeders described by Coves et al. (1998) and were fed industrial sea bass food with an average composition of 44 to $52 \%$ proteins, $1.5 \%$ phosphorus, $22 \%$ fat, $2 \%$ crude fibre and $10 \%$ ash. The trigger was connected to a HUSKY ${ }^{\circledR}$ computer which recorded the daily Distributed Food (DF). The Non Ingested Food (NIF) was collected in the particle traps and measured daily.

\subsection{Sampling and analysis}

\subsubsection{Fish biometrics}

During one year, the average weight of the fish, $\mathrm{m}$ (g) was measured every month on a random sample of forty fish after $24 \mathrm{~h}$ starvation. Phenoxy-ethanol was used as an anesthetic at $150 \mathrm{ppm}$ and $300 \mathrm{ppm}$ to sample the fish and weigh them. At the end of the experiment, all the fish were counted in each tank.

The fish density $\mathrm{D}_{\mathrm{f}}\left(\mathrm{kg} \mathrm{m}^{-3}\right)$ formula was calculated using:

$$
\mathrm{Df}=\mathrm{m} \times \mathrm{N} /\left(1000 * \mathrm{~V}_{\mathrm{t}}\right)
$$


with $\mathrm{V}_{\mathrm{t}}=$ volume of the rearing tanks $\left(\mathrm{m}^{3}\right) ; \mathrm{N}=$ number of fish in the tanks.

and the specific growth rate SGR $\left(\%\right.$ day $\left.^{-1}\right)$ :

$\operatorname{SGR}=\left[\ln \left(m_{\mathrm{f}}\right)-\ln \left(\mathrm{m}_{\mathrm{i}}\right)\right] \times 100 / \mathrm{t}$

with $\mathrm{m}_{\mathrm{i}}=$ initial average weight $(\mathrm{g}) ; \mathrm{m}_{\mathrm{f}}=$ final average weight $(\mathrm{g})$; $\mathrm{t}=$ time (day).

\subsubsection{Food intake}

The daily ingested food, DIF ( $\mathrm{g} \mathrm{day}^{-1} \mathrm{fish}^{-1}$ ) was calculated as follows:

$\mathrm{DIF}=(\mathrm{DF}-\mathrm{NIF}) /\left[\mathrm{t} \times\left(\mathrm{N}_{\mathrm{i}}+\mathrm{N}_{\mathrm{f}}\right) / 2\right]$

with DF = distributed food (g); NIF = non ingested food (g); $N_{i} \& N_{f}=$ initial \& final number of fish in the tanks; $\mathrm{t}=$ time (day).

and the food conversion ratio, FCR:

$\mathrm{FCR}=(\mathrm{DF}-\mathrm{NIF}) /\left[\left(\mathrm{m}_{\mathrm{f}} \times \mathrm{N}_{\mathrm{f}}\right)-\left(\mathrm{m}_{\mathrm{i}} \times \mathrm{N}_{\mathrm{i}}\right)\right]$

\subsubsection{Nutrient removal by HRAP}

Water was sampled 3 times per week for dissolved nutrient measurements in each circuit during four periods of two months corresponding to the seasons. Thirty millilitres of water were collected at 9 o'clock at the exit of one of the fish tank in the FTS and at the entrance of the biological filter in the 
RAS and RAS+HRAP. They were filtered through glass-fiber filters (GF/C Whatmann $\left.{ }^{\circledR}\right)$ and analyzed immediately or stored in plastic tubes at minus $4^{\circ} \mathrm{C}$ for further analysis. The analysis were made with a Technicon Autoanalyser II . Total ammonia nitrogen (TAN) concentration was measured using the method described by Solorzano (1969). Nitrites $\left(\mathrm{NO}_{2}^{-}\right)$were measured by molecular absorption method described by Bendschneider and Robinson (1952). The same method was used for nitrates $\left(\mathrm{NO}_{3}{ }^{-}\right)$after a primary reduction to nitrites on a cadmium-copper column (Wood et al., 1967). The sum of these three components is equal to dissolved inorganic nitrogen (DIN). Determination of phosphates $\left(\mathrm{PO}_{4}{ }^{3-}\right)$ was carried out using the spectrophotometric method (AFNOR NF T 90-023) described by Murphy and Riley (1962).

HRAP removals $\left(R_{\text {HRAP }}\right.$ g.m ${ }^{-2}$ day $\left.^{-1}\right)$ were the average \pm standard deviation $(\mu \pm S D)$ of two month values calculated for each season by comparison of the nutrient levels in the two recirculating systems. Removal rates were expressed according to the total HRAP surface $\left(24 \mathrm{~m}^{2}\right)$ :

$\mathrm{R}_{\text {HRAP }}=\left[\left(\mathrm{RW}_{\mathrm{r}} \times\right.\right.$ nut $\left._{\mathrm{r}}\right)-\left(\mathrm{RW}_{\mathrm{rHRAP}} \times\right.$ nut $\left.\left._{\mathrm{rHRAP}}\right)\right] /\left(\mathrm{S}_{\mathrm{HRAP}} \times 1000\right)$

with, $\mathrm{RW}_{\mathrm{r}}=$ replacement water in RAS $\left(\right.$ liter.day $\left.{ }^{-1}\right) ; \mathrm{RW}_{\mathrm{HRAP}}=$ replacement water in RAS $+\mathrm{HRAP}$ $\left(\right.$ liter.day $\left.{ }^{-1}\right)$; nut $_{\mathrm{r}}=$ nutrient concentration in RAS $\left(\mathrm{mg}^{-1} \mathrm{l}^{-1}\right)$; nut $_{\text {rHRAP }}=$ nutrient concentration in RAS + $\operatorname{HRAP}\left(\mathrm{mg} \cdot \mathrm{l}^{-1}\right) ; \mathrm{S}_{\mathrm{HRAP}}=$ surface of the $\operatorname{HRAP}\left(\mathrm{m}^{2}\right)$.

In order to estimate their influence on the HRAP removal capacities, water temperature in the ponds and incident light were recorded every five minutes by mobile instruments (HOBO H08 \& Temp Pro).

\subsubsection{Parameter control}

Temperature, oxygen concentration and salinity were measured every morning in the fish tanks with hand-held devices. Replacement water flow rates were checked every day and adjusted, when 
necessary, in the three systems. $\mathrm{pH}$ was measured three times a week, at the nutrient sampling spots (see paragraph below) with an $\mathrm{Ag} / \mathrm{AgCl}$ reference electrode $\left(\mathrm{ORION}^{\circledR}\right)$ and soda $(1 \mathrm{~N})$ was added in both recirculating systems when it was found below 6.5 .

\subsection{Statistics}

Data on nutrient concentrations were analyzed using a one way analysis of variance (ANOVA) with the rearing system (FTS, RAS, RAS+HRAP) as the factor. Data on fish weight was analyzed using a two way analysis of variance (ANOVA) with the rearing tank (1 or 2) and the rearing system (FTS, RAS, RAS+HRAP) as the factors. When the variances were not homogeneous and/or the residuals deviated from normality, the data were ln transformed prior to statistical analysis. If the ANOVA showed a significant difference $(* \mathrm{p}<0.05)$, a Newman-Keuls test (NK test) was carried out to compare the different groups. If the variances were still not homogeneous and/or the residual value deviated from the norm in spite of transformation, a non parametric test of Kruskal-Wallis (KW test) was carried out.

\section{Results}

\subsection{Water quality parameters}

Evolutions of temperature, oxygen concentration, salinity and $\mathrm{pH}$ between two fish biometric are presented Fig. 2. Some water parameters were difficult to maintain at a constant level all year long in the rearing systems. Salinity variations were due partly to the fresh water used to clean the mechanical filters of the recirculating systems and partly to the natural evolution of coastal water in FTS. Temperature in recirculating systems increased with indoor air temperature during the summer and a 
maximal temperature of $29{ }^{\circ} \mathrm{C}$ was reached in RAS. More soda was added in RAS compare to RAS+HRAP in order to stabilised $\mathrm{pH}$. An optimal level of oxygen concentration was difficult to maintain in FTS when density reached $70 \mathrm{~kg} \mathrm{~m}^{-3}$ at the end of the experiment.

Fig.2. Averages temperature, oxygen concentration, salinity and $\mathrm{pH}$ in the three rearing systems over one year (Errors bars: \pm SD)
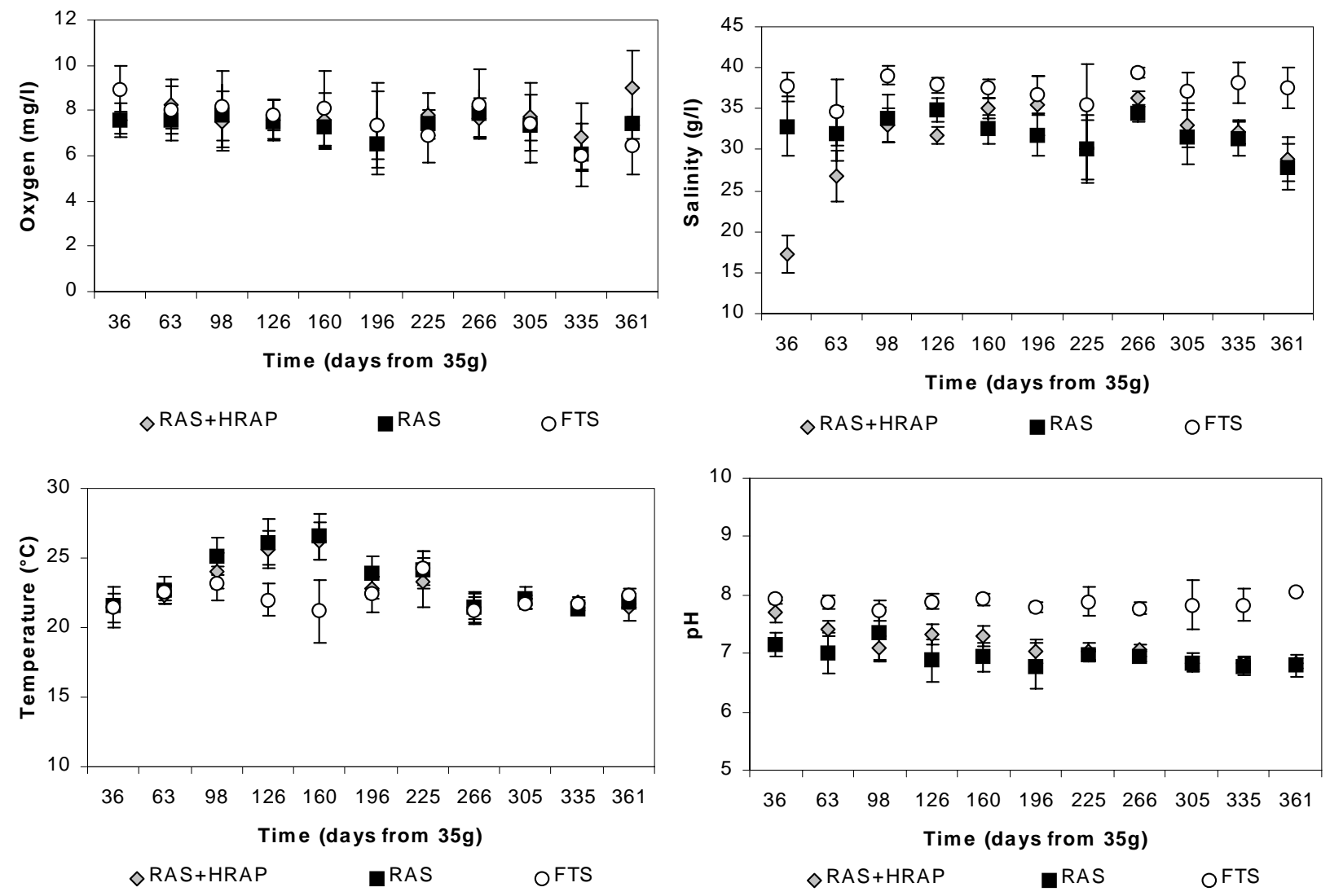

\subsection{Fish performances}

Average weight and density curves are shown in Fig.3. Daily ingested food results are given in Fig.4. Values of final weights and densities as well as specific growth rates and food conversion rates are presented in Table 2. Cumulative mortality rate is shown in Fig.5. 
Fig.3. Averages weight and density of fish in the three recirculating systems over one year (Errors bars: \pm SD)

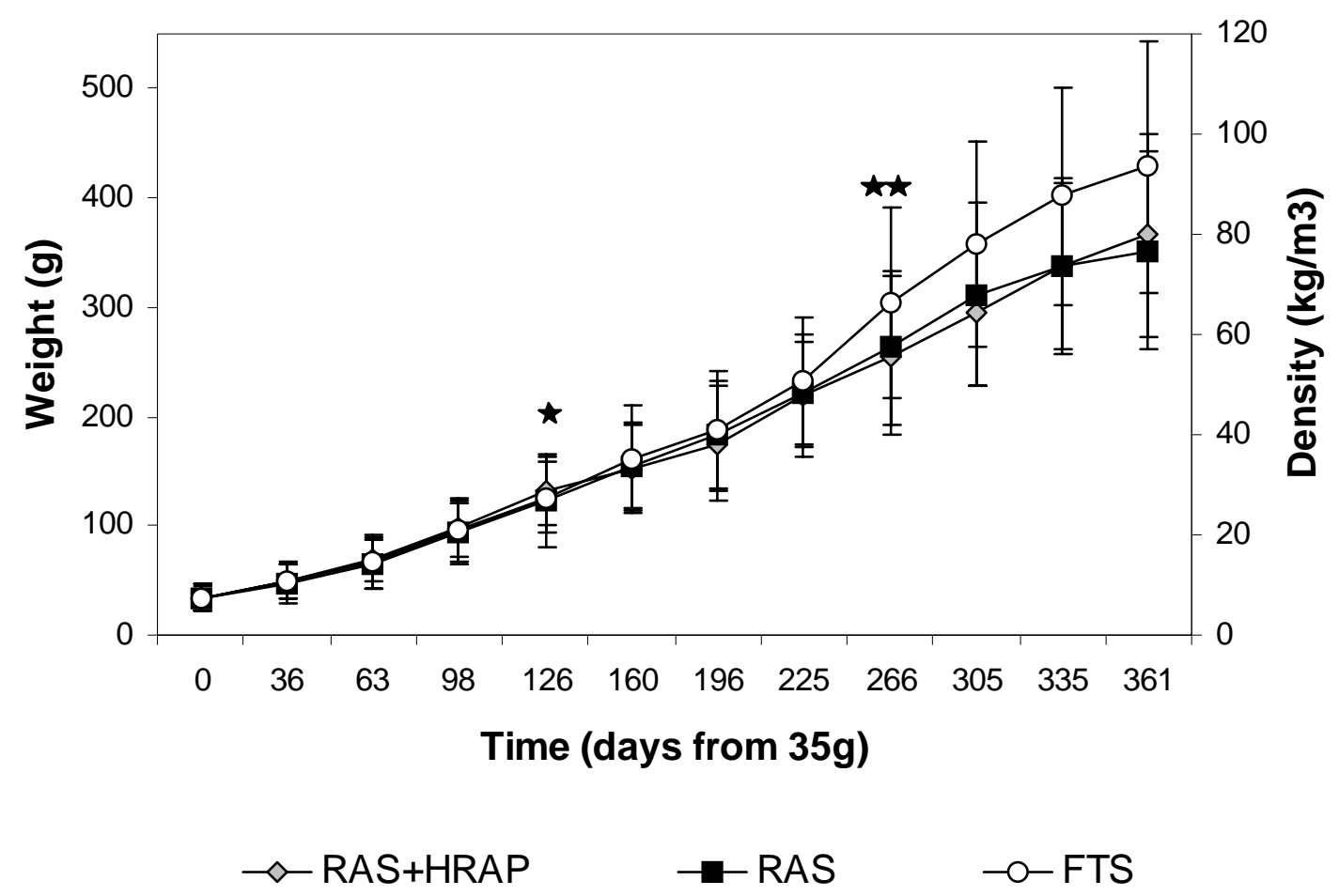

Table 2. Weight, density, specific growth rate (SGR), food conversion rate (FCR) and mortality of sea bass after one year of rearing in three different systems: flow through (FTS), recirculating (RAS) and recirculating with the high rate algae pond treatment (RAS+HRAP)

\begin{tabular}{cccccc}
\hline Rearing systems & $\begin{array}{c}\text { Weight } \pm \text { SD } \\
(\mathrm{g})\end{array}$ & $\begin{array}{c}\text { Density } \pm \text { SD } \\
\left(\mathrm{kg} \mathrm{m}^{-3}\right)\end{array}$ & $\begin{array}{c}\text { SGR } \\
\left(\% \mathrm{~d}^{-1}\right)\end{array}$ & FCR & $\begin{array}{c}\text { Mortality } \\
(\%)\end{array}$ \\
\hline RAS + HRAP & $366 \pm 93^{\mathrm{a}}$ & $82 \pm 22^{\mathrm{a}}$ & 0.66 & 1.58 & 3.5 \\
RAS & $351 \pm 90^{\mathrm{a}}$ & $79 \pm 21^{\mathrm{a}}$ & 0.65 & 1.69 & 7.3 \\
FTS & $429 \pm 115^{\mathrm{b}}$ & $94 \pm 25^{\mathrm{b}}$ & 0.70 & 1.53 & 7.8 \\
\hline
\end{tabular}

Weight and density are means \pm standard deviation. Means with different superscript are significantly different $(\mathrm{p}<0.05)$ 
Fig.4. Average daily ingested food of fish in the three rearing systems.

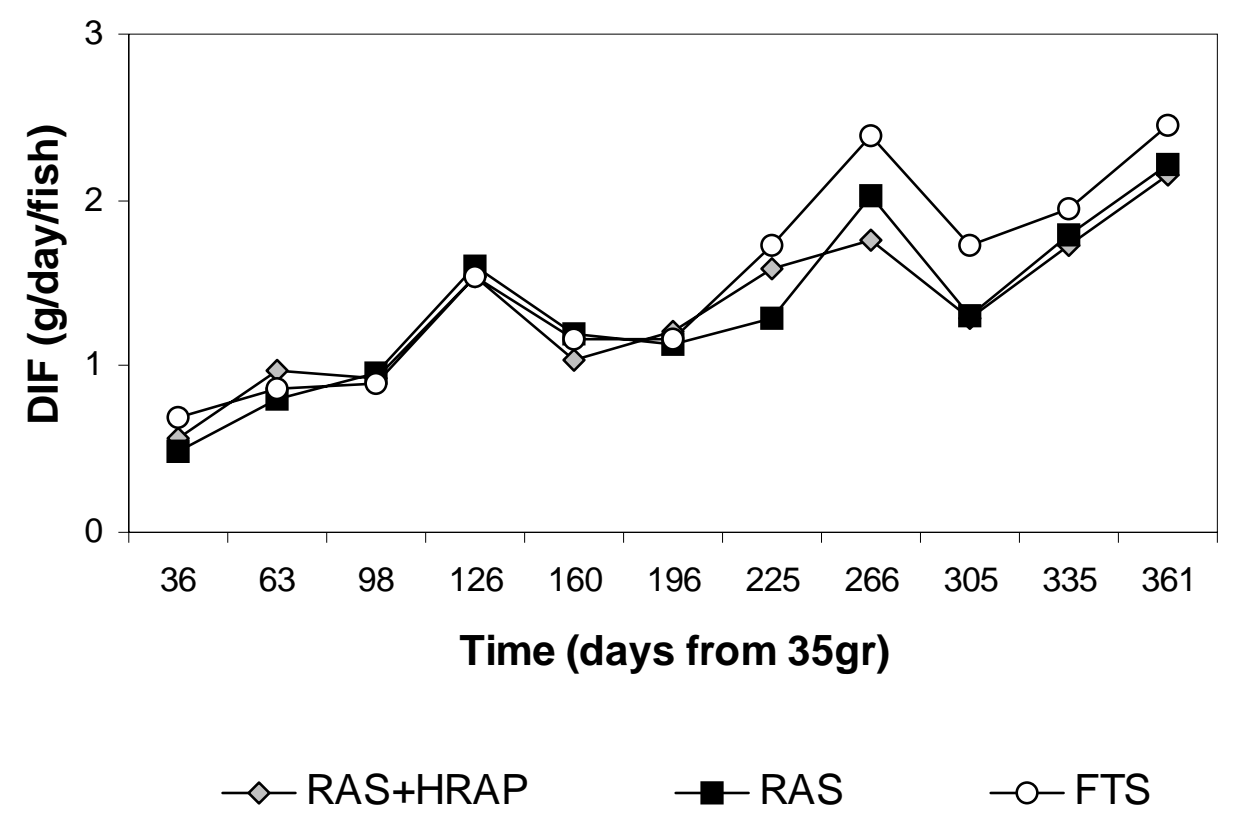

Fig.5. Cumulative mortality rate of fish in the three rearing systems over one year

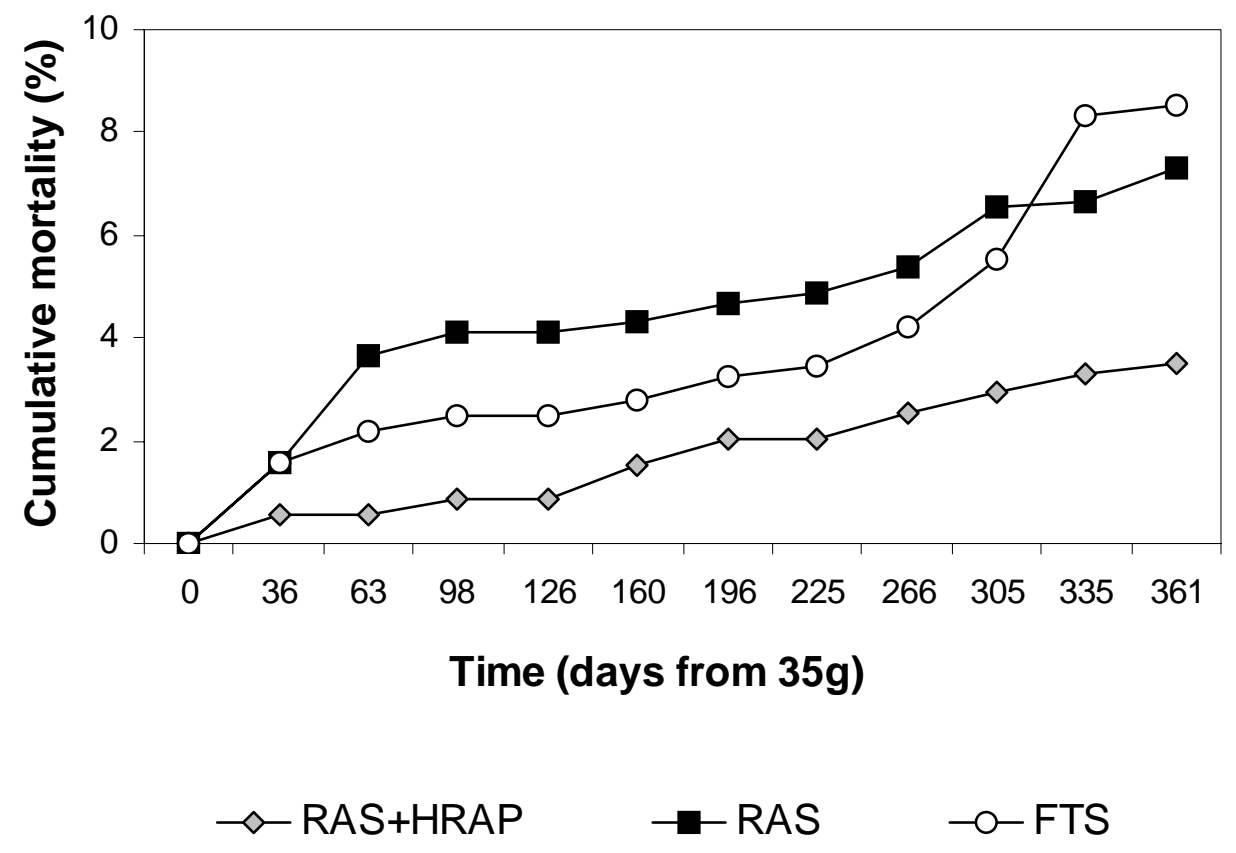


During the experiment, fish growth was the same between the 2 tanks of the same system but was significantly different between the three systems ( 2 way-ANOVA , $p=0.483 \& p<0.001$ between tanks and systems respectively). Since there was no significant difference between duplicates, data were pooled.

The growth between systems is globally the same for fish comprised between 35 and $200 \mathrm{~g}$ except after 126 days of rearing where the average weight of fish from RAS+HRAP is significantly higher ( $\mathrm{p}<0.05$ ). This gain is slight ( $4 \%$ and $6 \%$ compared to FTS and RAS respectively) and is related to the period of the year with the greatest incident light $\left(90 \mu \mathrm{E} / \mathrm{m}^{2} / \mathrm{d}\right)$ and the maximal algae growth in the HRAP (unpublished data). This benefit declined after this period. The fish growth rate was better in the flow-through system after 266 days' rearing resulting in higher mean weight (15\% on average), with a density of $50 \mathrm{~kg} \mathrm{~m}^{-3}$ and an average weight of $200 \mathrm{~g}$ (NK test, $\mathrm{p}<0.05$ ). This trend was maintained until the end of the experiment. After one year, this difference was about $15 \%$ on average. The density increased with the average weight and is statistically different at the end of the experiment in the FTS (NK test, $\mathrm{p}<0.05$ ). A similar trend was observed for SGR, 0.7, 0.66 and 0.65 in the FTS, RAS+HRAP and RAS, respectively.

The daily ingested food was statistically the same in the three systems (ANOVA, $\mathrm{p}=0.5$ ) but was higher in the FTS after 225 days’ rearing and this trend held through to the end of the experiment. The population of the FTS had the lowest FCR value (1.53), while the highest value occurred in the RAS (1.69).

Fish mortality was less than $10 \%$ per year in all the systems and was lower in the RAS+HRAP. No pathology was observed during the experiment and no chemical treatment was used. 


\subsection{Effect of HRAP on dissolved nutrients}

The seasonal and annual average concentration of nutrients in the different systems are presented in

Table 3. Ammonia was measured as total ammonia nitrogen in our circuits. Unionised ammonia (UNA), that is 300-400 times more toxic than $\mathrm{NH}_{4}^{+}$(Haywood, 1983), was calculated using the equation of Johansson and Wedborg (1980).

Table 3. Seasonal and annual concentrations of dissolved nutrients in the three rearing systems: flow through (FTS), recirculating (RAS) and recirculating with the high rate algae pond (RAS+HRAP)

\begin{tabular}{|c|c|c|c|c|c|c|c|}
\hline Season & $\begin{array}{l}\text { Rearing } \\
\text { systems }\end{array}$ & $\begin{array}{l}\mathbf{P}-\mathbf{P O}_{4}{ }^{3-} \\
\left(\mathrm{mg} . \mathrm{l}^{-1}\right)\end{array}$ & $\begin{array}{l}\text { N-NID } \\
\left(\mathrm{mg} . l^{-1}\right)\end{array}$ & $\begin{array}{l}\mathbf{N}-\mathrm{NO}_{3}{ }^{-} \\
\left(\mathrm{mg} \cdot \mathrm{l}^{-1}\right)\end{array}$ & $\begin{array}{l}\mathrm{N}-\mathrm{NO}_{2}^{-} \\
\left(\mathrm{mg} . \mathrm{l}^{-1}\right)\end{array}$ & $\begin{array}{l}\text { N-TAN } \\
\left.\left(\mathrm{mg}^{-1}\right)^{-1}\right)\end{array}$ & $\begin{array}{l}\text { N-UIA } \\
\left(\mu g . l^{-1}\right)\end{array}$ \\
\hline \multirow{3}{*}{$\begin{array}{l}\text { Winter } \\
(\mathrm{N}=26)\end{array}$} & FTS & $0.02 \pm 0.01$ & $0.2 \pm 0.1$ & $0.2 \pm 0.1$ & $0.00 \pm 0.00$ & $0.09 \pm 0.04$ & $3.0 \pm 2.0$ \\
\hline & RAS & $2.00 \pm 0.28 *$ & $14.9 \pm 2.7^{*}$ & $14.7 \pm 2.7^{*}$ & $0.08 \pm 0.04$ & 0.12 & $2.0 \pm 2.0$ \\
\hline & RAS+HRAP & $1.57 \pm 0.41^{*}$ & $10.0 \pm 2.2^{*}$ & $9.8 \pm 2.2 *$ & $0.05 \pm 0.02$ & 0.14 & $3.0 \pm 2.0$ \\
\hline \multirow{3}{*}{$\begin{array}{l}\text { Spring } \\
(\mathrm{N}=26)\end{array}$} & FTS & $0.02 \pm 0.01$ & $0.3 \pm 0.2$ & $0.1 \pm 0.2$ & $0.02 \pm 0.01$ & $0.12 \pm 0.09$ & $4.0 \pm 4.0$ \\
\hline & RAS & $1.67 \pm 0.37$ & $17.3 \pm 4.0^{*}$ & $16.9 \pm 4.0^{*}$ & $0.13 \pm 0.06$ & $0.22 \pm 0.14$ & $1.0 \pm 1.0$ \\
\hline & RAS+HRAP & $1.52 \pm 0.28$ & $11.3 \pm 2.5^{*}$ & $10.8 \pm 2.4^{*}$ & $0.15 \pm 0.07$ & $0.29 \pm 0.15$ & $5.0 \pm 2.0$ \\
\hline \multirow{3}{*}{$\begin{array}{l}\text { Summer } \\
(\mathrm{N}=24)\end{array}$} & FTS & $0.02 \pm 0.01$ & $0.2 \pm 0.1$ & $0.2 \pm 0.1$ & $0.00 \pm 0.00$ & $0.16 \pm 0.04$ & $6.0 \pm 2.0$ \\
\hline & RAS & $1.44 \pm 0.31^{*}$ & $16.3 \pm 5.0 *$ & $15.9 \pm 4.9 *$ & $0.11 \pm 0.04$ & $0.32 \pm 0.07$ & $2.0 \pm 1.0$ \\
\hline & RAS+HRAP & $1.19 \pm 0.29 *$ & $12.3 \pm 2.1^{*}$ & $11.9 \pm 2.0^{*}$ & $0.10 \pm 0.02$ & $0.35 \pm 0.13$ & $5.0 \pm 4.0$ \\
\hline \multirow{3}{*}{$\begin{array}{l}\text { Autumn } \\
(\mathrm{N}=19)\end{array}$} & FTS & $0.05 \pm 0.02$ & $0.4 \pm 0.1$ & $0.1 \pm 0.1$ & $0.00 \pm 0.00$ & $0.33 \pm 0.06$ & $8.0 \pm 1.0$ \\
\hline & RAS & $1.52 \pm 0.25$ & $15.4 \pm 4.4$ & $14.9 \pm 4.4$ & $0.14 \pm 0.08$ & $0.40 \pm 0.08$ & $1.0 \pm 0.1$ \\
\hline & RAS+HRAP & $1.82 \pm 0.18$ & $16.0 \pm 3.2$ & $15.5 \pm 3.2$ & $0.13 \pm 0.03$ & $0.40 \pm 0.10$ & $2.0 \pm 1.0$ \\
\hline \multirow{3}{*}{$\begin{array}{l}\text { Annual } \\
(\mathrm{N}=95)\end{array}$} & FTS & $0.03 \pm 0.02$ & $0.4 \pm 0.2$ & $0.1 \pm U .1$ & $0.01 \pm 0.01$ & $0.24 \pm 0.16$ & $5.0 \pm 3.0$ \\
\hline & RAS & $1.56 \pm 0.33^{*}$ & $17.3 \pm 5.2^{*}$ & $16.9 \pm 5.2 *$ & $0.12 \pm 0.06$ & $0.30 \pm 0.12$ & $2.0 \pm 1.0$ \\
\hline & RAS+HRAP & $1.70 \pm 0.52 *$ & $14.8 \pm 5.3 *$ & $14.5 \pm 5.1^{*}$ & $0.13 \pm 0.05$ & $0.34 \pm 0.12$ & $4.0 \pm 3.0$ \\
\hline
\end{tabular}

Values are means \pm standard deviation. ${ }^{*}$ Statistically significant difference $(p<0.05)$ between RAS and RAS+HRAP.

The seasonal and annual average nutrient removals by HRAP are showed in Table 4 . We checked that the $\mathrm{R}_{\text {feed/water }}$ ratio is statistically the same in the two recirculating systems during the water sample 
periods in winter (ANOVA, $\mathrm{p}=0.80$ ), spring ( $\mathrm{KW}$ test, $\mathrm{p}=0.07$ ), summer (KW test, $\mathrm{p}=0.27$ ) and autumn (ANOVA, p=0.75).

Table 4. Seasonal and annual removal rates of dissolved nutrients by the two high rate algae ponds comparing nutrients concentrations in the RAS and the RAS+HRAP.

\begin{tabular}{|c|c|c|c|c|c|c|c|}
\hline & $\begin{array}{c}\text { TAN } \\
\text { removal } \\
\left(\mathrm{gN} \cdot \mathrm{m}^{-2} \cdot \mathrm{d}^{-1}\right)\end{array}$ & $\begin{array}{c}\mathrm{NO}_{3}^{-} \\
\text {removal } \\
\left(\mathrm{gN} \cdot \mathrm{m}^{-2} \cdot \mathrm{d}^{-1}\right)\end{array}$ & $\begin{array}{c}\mathrm{NO}_{2}^{-} \\
\text {removal } \\
\left(\mathrm{gN} \cdot \mathrm{m}^{-2} \cdot \mathrm{d}^{-1}\right)\end{array}$ & $\begin{array}{c}\text { DIN } \\
\text { removal } \\
\left(\mathrm{gN} \cdot \mathrm{m}^{-2} \cdot \mathrm{d}^{-1}\right)\end{array}$ & $\begin{array}{c}\text { PO4 } \\
\text { removal } \\
\left(\mathrm{gP} \cdot \mathrm{m}^{-2} \cdot \mathrm{d}^{-1}\right)\end{array}$ & $\begin{array}{c}\text { Daily } \\
\text { Temper. } \\
\left({ }^{\circ} \mathrm{C}\right)\end{array}$ & $\begin{array}{l}\text { Daily light } \\
\left(\mu \mathrm{E} \cdot \mathrm{m}^{-2} \cdot \mathrm{s}^{-1}\right)\end{array}$ \\
\hline \multicolumn{8}{|c|}{, } \\
\hline$\mu$ & -0.013 & 0.27 & -0.006 & 0.25 & -0.024 & 19 & 85 \\
\hline SD & 0.004 & 0.16 & 0.002 & 0.16 & 0.018 & 3 & 5 \\
\hline \multicolumn{8}{|c|}{ Summer } \\
\hline$\mu$ & -0.005 & 0.49 & 0.001 & 0.49 & 0.027 & 25 & 89 \\
\hline SD & 0.003 & 0.18 & 0.002 & 0.18 & 0.017 & 2 & 3 \\
\hline \multicolumn{8}{|c|}{ Autumn } \\
\hline$\mu$ & 0.009 & 0.27 & 0.005 & 0.28 & -0.009 & 10 & 50 \\
\hline SD & 0.006 & 0.24 & 0.003 & 0.25 & 0.025 & 4 & 4 \\
\hline \multicolumn{8}{|l|}{ Winter } \\
\hline$\mu$ & -0.002 & 0.09 & 0.001 & 0.09 & 0.002 & 12 & 46 \\
\hline SD & 0.001 & 0.09 & 0.001 & 0.09 & 0.013 & 2 & 11 \\
\hline \multicolumn{8}{|l|}{ Annual } \\
\hline$\mu$ & -0.005 & 0.37 & -0.0001 & 0.36 & 0.008 & 17 & 70 \\
\hline SD & 0.003 & 0.14 & 0.0010 & 0.14 & 0.016 & 7 & 21 \\
\hline
\end{tabular}

Values are means \pm standard deviation.

\subsubsection{Nutrient concentrations}

The lowest concentrations are observed in the FTS, where the nutrients were permanently flushed. Annual dissolved inorganic nitrogen $\left({ }^{* *} \mathrm{p}<0.01\right)$ and phosphate $\left({ }^{* *} \mathrm{p}<0.01\right)$ concentrations in the recirculating systems are significantly lower with the HRAP treatment.

Dissolved inorganic nitrogen is statistically lower in the RAS+HRAP compared to the RAS during winter (NK test, $\mathrm{p}<0.05$ ), spring ( $\mathrm{NK}$ test, $\mathrm{p}<0.05$ ) and summer ( $\mathrm{NK}$ test, $\mathrm{p}<0.05$ ) but is not different during autumn (KW test, $\mathrm{p}=0.08$ ). Absorption of nitrate, which is the accumulation form of nitrogen, is responsible for the lower concentration of DIN in the RAS+HRAP (NK test, $\mathrm{p}<0.05$ ). There is no 
statistical difference in ammonia concentrations between the two recirculating systems all year long. Phosphate concentration is statistically lower in the RAS+HRAP compared to the RAS during winter (KW test, $\mathrm{p}<0.001$ ) and summer (NK test, $\mathrm{p}<0.05$ ) but is not different during spring (ANOVA, $\mathrm{p}=0.09)$ and is higher in autumn (NK test, $\mathrm{p}<0.05)$.

\subsubsection{Nutrient removal rates}

The highest nitrogen removal occurred during summer with better climatic conditions and a higher harvesting rate (every 6 days). The lowest nitrogen removal was observed during winter, with the poorest climatic conditions and the lowest harvesting rate (every 14 days). Nitrogen removal is similar during spring and autumn. In spring, the climatic conditions are similar to summer but the harvesting rate is lower (every 14 days). In autumn, climatic conditions are closer to those in winter but the harvesting rate is higher (every 6 days). Throughout the year of the experiment, removal rate calculation confirms that the nitrate form is responsible for nitrogen removal in the HRAP.

The highest phosphate removal occurs during summer with the best climatic conditions, and harvesting rate. It is 10 times lower during winter and is negative during spring and autumn.

\section{Discussion}

One of the objectives of this study was to test the long-term effect of treated effluents on fish mortality and growth rates. Algae and zooplankton species which developed in the HRAP (Deddouche J., pers. com.) are commonly found in eutrophic water such as lagoons. The HRAP treated water did not induce fish mortality, biological filter disturbance or delays in fish growth. In the recirculating system with HRAP, the mortality rate was two times lower than in the other systems. The biological filter was 
efficient all year long in removing toxic ammonia as shown by its low concentration in the circuit. The small but significant higher mean weight of fish after the month of maximum photosynthetic activity is in accordance with a previous study that showed a better growth of sea bass reared in HRAP water compared to standard water (Salery, pers. com.). These results may suggest a favourable effect of the HRAP water on sea bass survival and growth when climatic conditions are maximal for photosynthesis of algae. Capacities of algae to produce and absorb various compounds may explain the phenomena observed. HRAP water quality is therefore compatible with complete reuse in a recirculating rearing system all year long.

Fish growth statistically decreased in both RAS compared to the FTS after 266 days of rearing. The difference in average weight is about $15 \%$ after one year. Several authors demonstrated that optimal temperature and $\mathrm{pH}$, for $\mathrm{D}$. labrax growth, were situated between $20-25^{\circ} \mathrm{C}$ (Claireaux and Lagardère 1999) and 6.1-8 (Lemarié et al., 2000), respectively. In other respects, recent experimentation showed that 3 months are necessary to obtain a $10 \%$ decrease of the final average weight at a constant rearing temperature of $29{ }^{\circ} \mathrm{C}$ compared to $25{ }^{\circ} \mathrm{C}$ (Person-LeRuyet, pers. com.). They did not observe any effect on sea bass growth in this range of values. Sea bass can also tolerate a high range of salinity (10$40 \mathrm{~g} / \mathrm{l})$ but their metabolism tend to decrease with the salinity: the higher growth and increased daily feed rate were observed at intermediary salinity (Bœuf and Payan, 2001). However, Claireaux and Lagardère (1999) showed that significant differences in growth occurred only between 5 and 20 g/l. During the experiment, some parameters were over the range for optimal growth in the three circuits. Nevertheless, no simple correlation was found between growth and temperature, $\mathrm{pH}$, salinity or oxygen concentration.

The analysis of growth factors (DIF, SGR, FCR) showed that the higher growth of fishes in the FTS is due to an increased ingested food. Among the factors that could be responsible of a decreased SGR 
and DIF in the recirculating systems, the accumulation of a toxic substance is a major hypothesis. TAN and UIA were far from $6.6 \mathrm{mg} \mathrm{l}^{-1}$ and $0.26 \mathrm{mg} \mathrm{l}^{-1}$, respectively, which are the chronic sub-toxic concentrations for sea bass (Lemarié et al., in press). Lemarié and Toften (2003) showed that accumulation of excretion products, due to a reduced water flow rate below $20 \mathrm{l} \mathrm{h}^{-1} \mathrm{~kg}^{-1}$ (of fish) in a flow through system, led to lower feed intake and sea bass growth and concluded that carbon dioxide is mainly responsible of the reduced performance. They also recorded abnormal behaviour such as lethargy and loss of reflex, that we also observed during the biometrics. In the recirculating systems carbon dioxide concentration of the water entering the fish tanks was higher than in the FTS in spite of the degassing column. In our circuits, the water renewal rate of $20 \mathrm{l} \mathrm{h}^{-1} \mathrm{~kg}^{-1}$ was reached when the fish biomass was $75 \mathrm{~kg} \cdot \mathrm{m}^{-3}$. The limiting carbon dioxide concentration was obtained earlier in the recirculating systems because of the higher residual concentration.

Over a year, the HRAP decreased the dissolved inorganic nitrogen concentration by $25 \%$ and the phosphate concentration by $9 \%$. The maximal nitrogen and phosphate removal rates occur during summer with the highest incident light and temperature. A weekly harvesting rate for seaweed led to double nitrogen removal in the ponds because it decreased the risk of nutrient release by dead algae and maintained optimal density for algae growth (Neori et al., 1991; Jiménez del Rio et al., 1994) which depend highly on light penetration in the water column (Richmond et al., 1980).

If nitrogen removal is related to climatic conditions for algae growth during each season, it is not only the case of the phosphates. Phosphate removal was negative at two occasions (spring and autumn) even though nitrogen removal was positive. This could be explained by the two processes acting on phosphates in HRAP: algae absorption and orthophosphate precipitation or dissolution around $\mathrm{pH} 8$ (Moutin et al., 1992; Mesplé et al., 1996). In other prospects, a high pH level could have been reached locally around the soda injection spot in the RAS. 
In a previous study, Pagand et al., (2000b) obtained three and five times higher maximal nitrogen and phosphate removal rates respectively. This could be explained by some differences in his method: (1) the time of water sampling (14:00) which corresponded to a daily maximal photosynthesis (2) the low

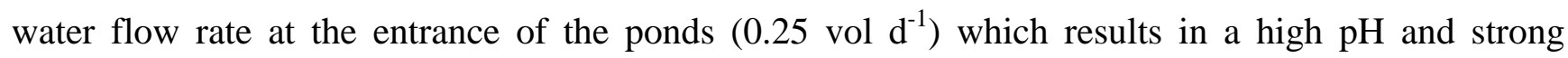
precipitation of phosphates and (3) a more precise calculation of HRAP removal capacities by comparison of nutrient concentrations at the entrance and the exit of the pond.

In our HRAP, supplied with a high nitrate effluent from an RAS, the nitrogen removal capacities of the algae was due to nitrate absorption. It was not the case with low ammonia effluent (around $1.4 \mathrm{mg} \mathrm{l}^{-1}$ N-TAN) as shown by Neori (1996). He described that nitrate accumulation greatly reduces nitrogen removal capacity of the seaweed relative to ammonia and proposed limiting nitrification in such systems. He obtained a two to three times higher nitrogen removal rate in the algae pond related to a two times higher water exchange rate $\left(3.3 \mathrm{vol} \mathrm{d} \mathrm{d}^{-1}\right)$. This difference may be due to the preference of the algae in taking up ammonia over nitrate (D’Elia and DeBoer, 1978; Rosenberg and Ramus, 1984) and/or to a carbon depletion in our ponds already described in vitro (Parker, 1981) and in natural waters (Levavasseur et al., 1991). According to the nutrient budget for the photosynthesis of macroalgae, the C/N/P ratio of the fish effluent should be equal to 550/30/1 (Atkinson and Smith, 1983). The algae uses the inorganic carbon (IC) source for photosynthesis, that is the carbonate system in seawater. The IC concentration in natural seawater is around $30 \mathrm{mg} \mathrm{l}^{-1}$. If we consider this value in the case of low ammonia effluents, the ratio is more or less respected, although there is a depletion of carbon in recirculating effluents. The IC concentration of our effluent should be around $250 \mathrm{mg} \mathrm{l}^{-1}$ regarding the nitrogen and phosphorus values. 
In order to improve nitrogen and phosphate removal in the RAS+HRAP there is (1) the possibility of increasing the flow of inorganic carbon by increasing the water flow rate in the algae ponds and (2) of choosing the better intake and return points in the RAS to obtain more $\mathrm{CO}_{2}$ enriched effluent for seaweed photosynthesis.

\section{Conclusion}

Sea bass growth rates were compared in 3 rearing systems: flow-through (FTS), recirculating aquaculture system (RAS) and recirculating aquaculture system with reuse of the waste water after treatment in a HRAP (RAS+HRAP).

The reuse of HRAP treated water didn't decrease fish growth in RAS over a one year range and even improved it during the month of maximal photoperiod. It also had a positive effect on fish survival, and the nitrification in the biological filter was not reduced. These results are favourable to complete reuse of the HRAP treated water, all year long, in the rearing systems.

The mean weights were similar in the three systems up to an average weight of $200 \mathrm{~g}$ and a fish density of $50 \mathrm{~kg} \cdot \mathrm{m}^{-3}$ in the tanks. Afterwards, fish growth was better (15\% on average) in the FTS compared to the two RAS. This slower growth in the RAS cannot be only explained by the concentration levels of the rearing parameters. Accumulating substances related to high fish density (carbon dioxide level in the tanks and other substances originating from the industrial food) and there combined effect are probably to be looked for.

On a one year range, the HRAP decreased the dissolved inorganic nitrogen and the phosphate concentration by $25 \%$ and $9 \%$ respectively. The maximal nitrogen and phosphate removal rates, $0.5 \pm$ $0.2 \mathrm{gN} . \mathrm{m}^{-2} \cdot \mathrm{d}^{-1}$ and $0.03 \pm 0.02 \mathrm{gP} \cdot \mathrm{m}^{-2} \cdot \mathrm{d}^{-1}$ respectively, occurred during summer with the better climatic 
conditions and higher harvesting rates for seaweed. The absorption of nitrate is responsible for nitrogen removal and precipitation of phosphate should be taken into account to explain its removal. Higher renewal rates in the HRAP should improve the inorganic carbon inflow, algae growth and nutrient removal.

\section{References}

Atkinson, M.J., Smith, S.V., 1983. C :N :P ratios of benthic marine plants. Limnol. Oceanogr. 28, 568-574.

Benschneider, K., Robinson, R. J., 1952. A new spectrophotometric determination of nitrite in seawater. J. Mar. Res. 11, 87-96.

Blancheton, J.P., 2000. Developments in recirculation systems for Mediterranean fish species. Aquacult. Eng. 22, 17-31.

Bœuf, G., Payan, P., 2001. How should salinity influence fish growth ? Comp. Biochem. Phys. C. 130, 411-423.

Claireaux, G., Lagardère, J.P., 1999. Influence of temperature, oxygen and salinity on the metabolism of the European sea bass. Journal of Sea Research, 42: 157-168.

Cohen, I., Neori, A., 1991. Ulva lactuca biofilters for marine fishpond effluents. I. Ammonia uptake kinetics and nitrogen content. Bot. Mar. 34, 475-482.

Covès D., Gasset E., Lemarié G., Dutto G., 1998. A simple way to avoiding feed wastage in European seabass, Dicentrarchus labrax, under self-feeding conditions. Aquat. Living Resour. 11(6), 395401.

D’Elia, C.F., DeBoer, J.A., 1978. Nutritional studies of two red algae. II. Kinetics of ammonium and nitrate uptake. J. Phycol. 14, 266-272. 
Haywood, G.P., 1983. Ammonia toxicity in teleost fish: a review. Can. Tech. Rep. Aquat. Sci. 1177, 135.

Jiménez del Rio, M., Ramazanov, Z., Garcia-Reina, G., 1994. Optimisation of yield and biofiltering efficiencies of Ulva rigida C. Ag. cultivated with Sparus aurata L. wastewaters. Sci. Mar. 58, 329-335.

Jiménez del Rio, M., Ramazanov, Z., Garcia-Reina, G., 1996. Ulva rigida (Ulvales, Chlorophyta) tank culture as biofilters for dissolved inorganic nitrogen from fishpond effluents. Hydrobiologia. 326/327, 61-66.

Johansson, O., Wedborg, M., 1980. The ammonia-ammonium equilibrium in seawater at temperatures between 5 and $25^{\circ} \mathrm{C}$. J. Solut. Chem. 9, 37-44.

Lemarié, G., Dutto, G., Le Roux, A., Lemoalle, J., Maxime V., Person- Le Ruyet, J., 2000. Long-term effects of $\mathrm{pH}$ and carbon dioxide on growth and feed efficiency in European seabass. Abstracts of Responsible Aquaculture in the New Millenium, Conference AQUA 2000, May 2-6 2000, Nice, France. European Aquaculture Society, Special Publication, vol. 28, p. 484.

Lemarié, G., Toften, H., 2003. Water quality, feed intake and growth in european seabass (Dicentrarchus labrax L.) in relation to water renewal rate. Extended abstracts and Short Communications of International conference Aquaculture Europe 2003, Beyond monoculture, August 8-12, 2003, Trondheim, Norway, European Aquaculture Society, Special Publication, No 33, p. 242-243.

Lemarié, G., Dosdat, A., Covès, D., Dutto, G., Gasset, E., Person-Le Ruyet, J.. Effect of chronic ammonia exposure on growth of European seabass (Dicentrarchus labrax) juveniles. Aquaculture, in press.

Levavasseur, G., Edwards, G.E., Osmond, C.B., Ramus, J., 1991. Inorganic carbon limitation of photosynthesis in Ulva Rotundata (Chlorophyta). J. Phycol. 27, 667-672. 
Mesplé, F., Casellas, C., Troussellier, M., Bontoux, J., 1996. Modelling orthophosphate evolution in a high rate algal pond. Ecol. Model. 89, 13-21.

Moutin, T., Gal, J.Y., El Halouani, H., Picot, B., Bontoux, J., 1992. Decrease of phosphate concentration in a high rate pond by precipitation of calcium phosphate: theoretical and experimental results. Water Res. 26, 1445-1450.

Murphy, J., Riley, J.P., 1962. A modified single solution method for the determination of phosphate in natural waters. Anal. Chim. Acta. 27, 31-36.

Neori, A., 1996. The type of N-supply (ammonia or nitrate) determines the performance of seaweed biofilters integrated with intensive fish culture. Isr. J. Aquacult-Bamid. 48(1), 19-27.

Neori, A. Cohen, I., Gordin, H., 1991. Ulva lactuca biofilters for marine fishpond effluents, II. Growth rate, yield and C:N ratio. Bot. Mar. 34, 483-489.

Oswald, W.J., 1963. High rate pond in waste disposal. Dev. Ind. Biotechnol. 4, 112-119.

Pagand, P., Blancheton, J.P., Casellas, C., 2000 a. A model for predicting the quantities of dissolved inorganic nitrogen released in effluents from a sea bass (Dicentrarchus labrax) recirculating water system. Aquacult. Eng. 22, 137-153.

Pagand, P., Blancheton J.P., Lemoalle, J., Casellas, C., 2000 b. The use of high rate algal ponds for the treatment of marine effluent from a recirculating fish rearing system. Aquac. Res. 31, 729-736.

Parker, H.S., 1981. Influence of relative water motion on the growth, ammonium uptake and carbon and nitrogen composition of Ulva lactuca (chlorophyta). Mar. Biol. 63, 309-318.

Richmond, A., Vonshak, A., Shoshana (Malis) arad, 1980. Environmental limitations in outdoor production of algal biomass. In: Shelef and Soeder (Eds). Algae Biomass. Elsevier,.Amsterdam, pp. 65-72.

Rosenberg, G., Ramus, J., 1984. Uptake of inorganic nitrogen and seaweed surface area: volume ratios. Aquat. Bot. 19, 65-72. 
Schuenhoff, A., Shpigel, M., Lupatsch, I., Ashkenazi, A., Msuya F.E., Neori, A., 2003. A semirecirculating, integrated system for the culture of fish and seaweed. Aquaculture. 221, 167-181.

Solorzano, L., 1969. Determination of ammonia in natural waters by the phenolhypochlorite method. Limnol. Oceanogr. 14, 799-801.

Wood, E.D., Armstrong, F.A.J., Richards, F.A., 1967. Determination of nitrate in seawater by cadmium-copper reduction to nitrite. J. Mar. Biol. Assoc. UK. 47, 23-31. 